\title{
Racism Measurement Framework: A Tool for Public Health Action and Accountability
}

\author{
Saira Nawaz ; Kyle J. Moon ; Eric Seiber ${ }^{1}$; Anne Trinh; Suellen Bennett²; Joshua J. \\ Joseph $^{3}$
}

${ }^{1}$ Center for Health Outcomes and Policy Evaluation Studies, College of Public Health, The Ohio State University, Columbus, OH

${ }^{2}$ Center for Public Health Innovation, Columbus Public Health, Columbus, $\mathrm{OH}$

${ }^{3}$ Division of Endocrinology, Diabetes and Metabolism, College of Medicine, The Ohio State University, Columbus, $\mathrm{OH}$

Corresponding Author: Saira Nawaz, 1841 Neil Avenue, Columbus, OH 43210, (614) 292-4691, nawaz.16@osu.edu

Submitted August 20, 2020 Accepted November 23, 2020

\begin{abstract}
Racism is a principal determinant of health inequity, but recent events have galvanized local and state leaders across Ohio to declare racism a public health emergency. In addition to the renewed call to racial justice, sustained progress will require ongoing measurement to determine which anti-racist efforts are working, and why. In this review, we present existing measures categorized by 3 dimensions of racism that interact and build off of one another: (1) systemic racism, considering the health effects of policies in housing, voting, criminal legal system, economic opportunity, and health care; (2) interpersonal racism, and measures of provider bias and cultural competency; (3) internalized racism, measured as allostatic stress and heightened vigilance in distinct contexts. After identifying knowledge gaps, we developed a racism measurement framework that more comprehensively depicts the disparities caused by racism within Ohio and can be used to monitor and evaluate the effectiveness of anti-racist efforts implemented across the state. As such, this framework provides not only a call for action against racism in Ohio, but an opportunity for organizations to measure the extent to which efforts have intervened on supposedly entrenched pathways to health inequities and disparities caused by racism.
\end{abstract}

Keywords: Racism; Measurement framework; Health outcomes; Evaluation; Health disparities

\section{INTRODUCTION}

Racism has long been recognized as a principal determinant of health inequity, 1,2 but recent events have galvanized local and state leaders across the United States to declare racism a public health emergency,3,4 with at least 23 resolutions across the state of Ohio, including Franklin, Cuyahoga, Hamilton, Lorain, Summit, and Montgomery counties, along with the cities of Akron, Canton, Columbus, Cleveland, Dayton, and Youngstown, among others. ${ }^{5-17}$ Such declarations coincide with reports highlighting the disproportionate impact of COVID-19 on communities of color and the Black Lives Matter protests that were catalyzed by recent deaths at the hands of law enforcement. ${ }^{18-20}$ The dual crises of COVID-19 and long-standing racism have put health inequities into the center of our collective awareness, further supporting the Columbus City Council's demand for a "data-driven focus on poverty, eco- nomic mobility, and other factors that impact the social determinants of health (SDoH)."6 Several proposed conceptual models of SDoH address racism, ${ }^{21-23}$ but in the absence of a measurement framework there remains a gap in applying a data-driven approach that will enable health systems, government agencies, academic centers, community organizations, and public health professionals to combat racism.

Racism is an entrenched ideology in American society, with social and economic infrastructure designed to ingrain racial segregation.1,24,25 The enduring impact of the transatlantic slave trade, which began roughly 400 years ago, as well as the history of European imperialism and colonization, continue to the present day, with millions suffering from generational trauma caused by systemic racism. ${ }^{26}$ In a recent disciplinary self-critique, Hardeman and Karbeah describe how disciplines such as health services re- 
search do not challenge the underlying white framing ("the overarching worldview that encompasses important racial ideas, terms, images, emotion and interpretation, and lens by which white supremacy is perpetuated") of racial disparities in health outcomes, and call upon researchers to develop research questions and methodologies that "take apart and critically analyze health inequities within the context of the white racial frame."27 Our aim in this paper is to propose a measurement framework with a series of metrics that captures the multidimensionality of racism and its effects on health. The framework is intended to provide a comprehensive list of indicators to inform monitoring and evaluation of anti-racist strategies that tackle social and health deficits attributed to racism.

\section{METHODOLOGY}

Racism is "a system of structuring opportunity and assigning value based on the social interpretation of how one looks, that unfairly disadvantages some individuals and communities, unfairly ad- vantages other individuals and communities, and saps the strength of the whole society through the waste of human resources." 28 It is important to note that multiple definitions of racism exist; however, most consider racism to be multidimensional and functioning on multiple levels. Figure 1 illustrates our conceptual model of racism that draws heavily from Jones' theoretic framework and reflects dimensions of systemic racism, interpersonal racism, and internalized racism-and their points of intersection. ${ }^{29}$ We began our narrative review by reflecting on seminal articles of "Race and Health" as well as articles that emerged using the simple search term of "racism measurement."28-31 From there, we used citations (citations of the paper and citations within the paper) to expand our literature search to identify more recent reflections and measurement indicators. Literature was gathered as it aligned with the dimensions in the conceptual model: systemic, interpersonal, and internalized. Metrics were included in the measurement framework if they had been used in at least 2 studies related to the measurement and/or description of disparities caused by racism.
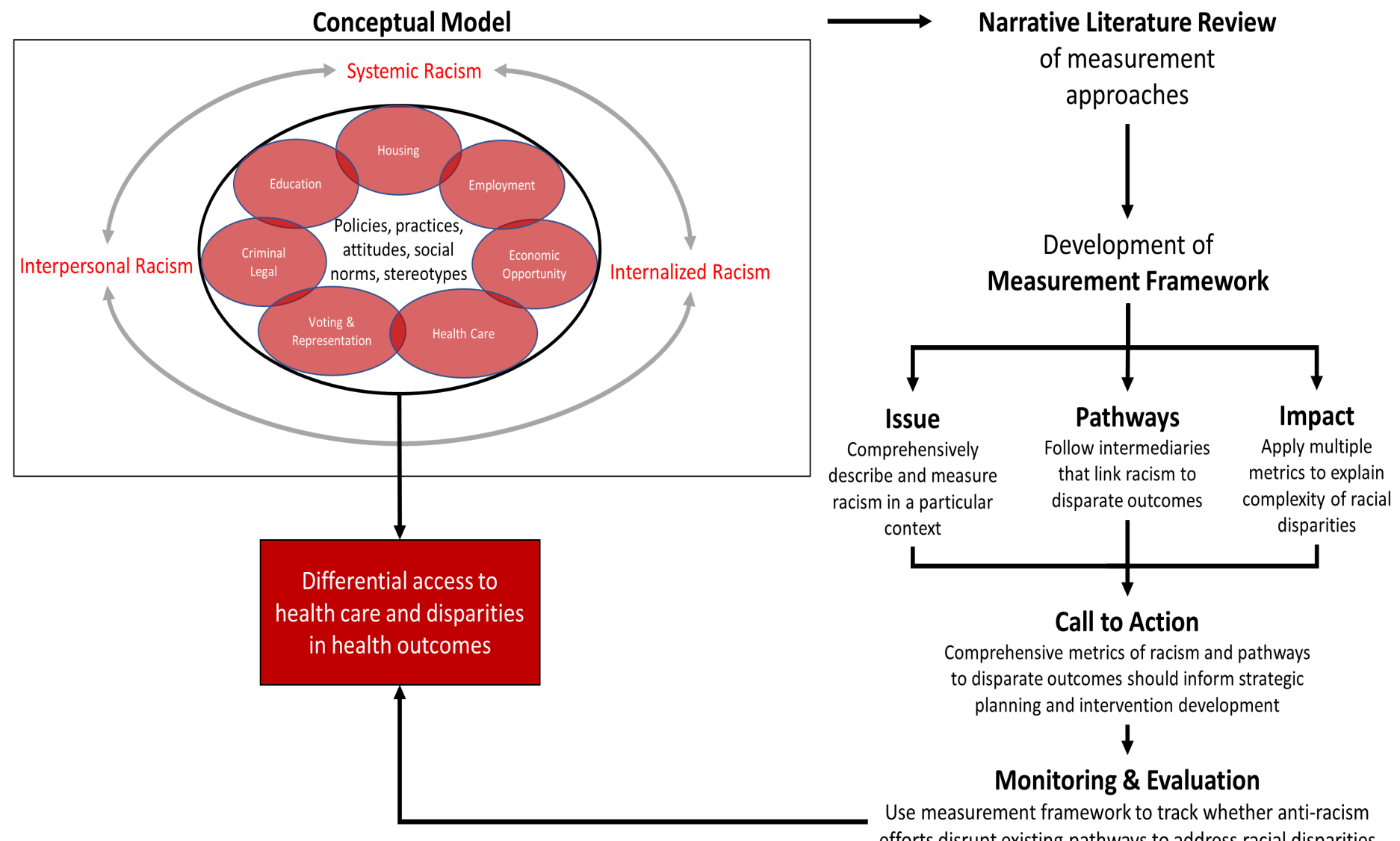

Use measurement framework to track whether anti-racism efforts disrupt existing pathways to address racial disparities and achieve equitable distribution of resources \& power

\section{Figure 1. Establishing Measurements for Dimensions of Racism and Action}

This conceptual model is informed by a review of the literature and reflects the established multidimensionality of racism, often organized into 3 distinct, yet overlapping, domains: systemic, interpersonal, and internalized. The measurement framework is developed to characterize the levels of racism, the impacts of racism, and the hypothesized pathways between racism and health outcomes. The framework can be used to develop a call for action to prioritize strategic planning goals and interventions that tackle racism at multiple levels and to monitor and evaluate whether those efforts are creating sustainable changes towards health equity. 
Gaps in measurement were identified from the literature as either a dimension where no metric was found or a metric with substantial quality concerns. Lastly, we present recommendations for how this framework can be applied in the public health context in Ohio to understand health disparities and assess the effectiveness of anti-racism activities across multiple dimensions of racism.

\section{MEASUREMENT FRAMEWORK FOR RACISM}

\section{Systemic Racism}

Systemic racism refers to the control of and access to labor, material, and symbolic resources within a society along racial lines. It is comprised of (1) structural racism, which involves the cumulative and compounding effects of an array of societal factors, including the history, culture, ideology, and interactions of institutions and policies that systematically privilege White people and disadvantage people of color; and (2) institutional racism, which refers to the unfair policies and discriminatory practices of particular institutions, such as schools and workplaces, that routinely produce racially inequitable outcomes for people of color and advantages for White people. ${ }^{30}$ It represents "the ways in which societies foster discrimination through mutually reinforcing inequitable systems...creating interconnected systems that embed inequities" in practices, laws, and policies. ${ }^{31}$ As such, systemic racism can be measured as the effects of policies on health (access and outcomes). In this section, we provide a brief overview of examples of racist policies and measures that track their impact on health outcomes. There are a number of well-established metrics for systemic racism in the policy sectors of housing, voting, criminal legal, economic opportunity, and health care, and Table 1 demonstrates how these metrics are linked to the SDoH and health outcomes.

\section{Housing}

Residential housing patterns are the most well-studied metric of systemic racism. Residential segregation affects socioeconomic status (SES) and social mobility, as residence determines access to education and employment opportunities. ${ }^{32,33}$ America's history of systematic and institutionalized racism led to "redlining," whereby neighborhoods were color-coded on maps, with communities of color designated as undesirable and color-coded red, making it more difficult and expensive for Black Americans to obtain loans and purchase homes. ${ }^{34}$ In 1937, the Home Owners' Loan Corporation redlining maps codified racial residential segregation into federal policy and practice from the 1940s through the 1960s, 25 where redlining remains at the heart of modern residential segregation metrics. For instance, contemporary Census tracts have been classified by the redlining maps to measure the Black-White disparity in odds of mortgage loan denial. ${ }^{35}$

Metrics. Two established measures include (1) index of dissimilarity, which is the proportion of Blacks or Whites who would have to move out of their neighborhood to achieve an even distribution, or complete integration; and (2) isolation, which is the degree to which Blacks have potential contact with non-Blacks. ${ }^{32}$

\section{Voting}

Measures of systemic racism in voting policy are outlined below. It is necessary to consider the effects of voter suppression laws, which are known to disproportionately affect people of color. As an example, $70 \%$ of voters in Georgia that were purged from the voter registration rolls were Black, ${ }^{36}$ and across the country, 1 in 13 Black Americans cannot vote because of restrictive measures that have disproportionate effects. ${ }^{36,37}$

Metrics. Established measures in voting policy include proportions of Blacks to Whites who (1) were registered to vote, (2) actually voted, and (3) were elected to the state legislature. ${ }^{38}$

\section{Criminal Legal}

Racial disparities in arrests and incarceration contribute to disparities in health outcomes caused by racism, with a recent study indicating that a greater number of criminal legal contacts among Black individuals contributes to more depressive symptoms, compared to White individuals. ${ }^{39}$ We also must understand how the outcomes of the criminal legal system vary based on the color of the victim. Studies of execution outcomes point to inequity of Black and White lives, as defendants convicted of killing White victims were executed at a rate 17 times greater than those convicted of killing Black victims. ${ }^{40,41}$

Metrics. Measures of racism in the criminal legal system include proportions of Blacks to Whites who were (1) incarcerated, (2) disenfranchised felons, and (3) on death row. 35,38

\section{Economic Opportunity}

There is a strong correlation between the racial opportunity gap and the racial mortality gap, reflecting how differences in health outcomes are tied to differences in income, poverty, unemployment, and education. ${ }^{42}$ When considering the effects of racism on economic opportunity, it is necessary to consider the generational accumulation of wealth and privilege. ${ }^{35,43}$ Wealth disparities stem from policies that perpetuated racial divides in the labor market, namely the New Deal's Fair Labor Standards Act of 1938 that largely excluded workers of color from its labor protections. ${ }^{44}$ While this policy has been expanded, agricultural and domestic workers are still exempt from many protections, where racial and ethnic minorities comprise $58-70 \%$ of the workforce. ${ }^{44}$

Metrics. Established measures of economic opportunity include (1) earnings rank gap, which is the sex-specific difference between a Black individual's percentile in the Black earnings distribution and the position in the White earnings distribution ${ }^{45}$; (2) racial opportunity gap, which is the sex-specific difference in income percentile ranking in adulthood between Black and White children born to families at the same income level in the same county ${ }^{42}$; and (3) proportions of Blacks to Whites who were (a) employed, (b) in the labor force, (c) in executive or managerial positions, (d) in professional specialties, and (e) college-educated. ${ }^{35,38}$ 


\section{Health care}

To assess systemic racism in health care policy, we consider racial biases in coverage and services received by both public and private insurers. In terms of coverage, the proportion of physicians participating in Medicaid is declining, influencing what health services exist in a given locale. ${ }^{46,47}$ Restricted health access for Medicaid patients disproportionately affects racial and ethnic minorities, who are 2.5 times more likely to have Medicaid coverage than non-Hispanic Whites. ${ }^{46,47}$ To add to the disparity, we see that White patients receive better quality of care than Black patients. ${ }^{48,49}$

Furthermore, health systems that rely on commercial prediction algorithms can exhibit significant racial bias, with Black patients having significantly greater illness burden than Whites at the same level of algorithm-predicted risk. ${ }^{50}$ Similarly, the Coronavirus Aid, Relief, and Economic Security (CARES) Act allocated funds to hospitals as a function of their past revenue, which disproportionately affected Black counties, who received the same level of relief funding as counties with lower COVID-19 burden and financial need. 51 Such racial biases arise because existing algorithms predict health care costs rather than illness, but health care costs are a poor proxy for health care needs because health-related expenditures are impacted by barriers to health care access. Notably, barriers to health care access may be further worsened in the transition to telehealth with the additional barriers of the digital divide and telehealth literacy, resulting in reduced use of health services among Black patients. ${ }^{52}$

Metrics. Measures include (1) proportions of physicians participating in Medicaid by county racial demographics or neighborhood segregation indices, (2) illness burden at same level of algorithm-predicted risk $^{47,50}$ and (3) digital divide associated with telehealth. 52

\section{Interpersonal Racism}

As previously noted, there is a considerable distinction between needing and receiving health care, which provides insight into interpersonal racism in health care. Interpersonal racism, whether intentional or unintentional, refers to discriminatory practices and beliefs directed at persons in the targeted social group by persons in the privileged, or dominant, social group, taking the form of suspicion, devaluation, scapegoating, and dehumanization.29,53 Interpersonal racism and systemic racism often overlap because these interpersonal practices and beliefs become embedded in structural relations. ${ }^{29}$ This interplay between interpersonal and systemic racism arises from power dynamics and extends across multiple sectors, with studies highlighting the negative effects of subtle indicators of racial identity on employers' perceptions of qualifications, competence, and "professionalism." ${ }^{54-56}$ Health care provider bias has particularly salient effects on health outcomes, as providers' perceptions regarding patients' value, self-reliance, competence, and deservingness lead to inequitable medical testing, referrals, treatment, procedures, and pain management.57-59
Providers' implicit biases are particularly pernicious towards Black women, often reinforcing stereotypes of Black women being uneducated, licentious, problematic drug users, with an overdependence on public assistance.60-62 Biases are present in more subtle ways, including exhibiting fewer positive, rapport-building nonverbal cues with Black patients. ${ }^{63}$

Interpersonal racism, in conjunction with systemic racism, contributes to the already disparate health outcomes in Ohio. It is important to note that the purpose of measurement is not to merely document disparities but to incite anti-racist action by identifying opportunities for intervention.64,65 Recognizing that these discrepancies in health outcomes are the result of social barriers, with provider bias being among the most frequently cited barrier, 66 medical education and health systems have adopted cultural competency training as a standard of practice, evidenced by the national standards for Culturally and Linguistically Appropriate Services (CLAS) in health care.67 Many studies, however, have deemed cultural competency training inadequate, and others have noted its ability to ignore oppressive structures of power and to compound cultural, ethnic, and racial stereotypes. ${ }^{68-71}$ As an alternative to cultural competency training, structural competency has been proposed as a framework for responding to social, political, and economic structures that influence the health of patients. ${ }^{70,72}$ The Structural Vulnerability Assessment Tool was developed for clinicians to take inventory of patient vulnerability and, in this way, can minimize the influence of provider biases on patient care plans. ${ }^{68}$

Metrics. Health services metrics provide a reliable means of capturing interpersonal racism between patients and providers as well as the interplay between interpersonal and systemic racism. Such metrics include patient satisfaction with health services and perceived quality of care; trust in health system and professionals ${ }^{73}$; communication and relationship with health service professionals; frequency of delaying, or simply not getting, health care; and visits and admissions to hospitals and emergency departments. ${ }^{74}$

\section{Internalized Racism}

The demarcation between interpersonal and internalized racism is often nebulous, which demonstrates that even though racism is multidimensional, these different levels interact and build off of one another. Internalized racism is the incorporation of attitudes, beliefs, or ideologies into one's worldview that maintain or exacerbate the unequal distribution of opportunity across ethnic and/or racial groups. ${ }^{75,76}$ Such racism takes on one of two forms: internalized oppression or internalized dominance, both of which hinge on the concept of embodiment, in which engagement with the material and social world transforms the body. ${ }^{76,77}$ As such, internalized racism can contribute to allostatic stress, causing accelerated aging and earlier onset of disease due to biological "weathering,"78 as well as patient disempowerment and fatalism, which negatively affect health care utilization and preventive care. ${ }^{79}$ 
A number of survey instruments exist, each tailored by target audience and survey length, including, but not limited to, the Everyday Discrimination Scale, Major Experiences of Discrimination, Chronic Work Discrimination and Harassment, Heightened Vigilance Scale, Index of Race-Related Stress (IRRS), Perceived Ethnic Discrimination Questionnaire (PEDQ), Workplace Prejudice/ Discrimination Inventory (WPDI), Experiences of Discrimination (EOD), Racism and Life Experience Scales (RaLES), Multidimensional Inventory of Black Identity (MIBI), Schedule of Racist Events (SRE), and Workplace Racial Bias Measure (WRB). ${ }^{30,80,81}$

Metrics. Surveys are a common measurement technique to assess internalized racism, such as the Perceived Racism Scale, which assesses behavioral and emotional responses to the experience of racism as well as frequency of exposure. ${ }^{82}$ Surveys typically ask about distinct contexts (workplace, health care, school, etc) to capture the interplay between internalized, interpersonal, and systemic racism. ${ }^{83}$ Despite their ubiquity, surveys' reliance on selfreport data presents a unique set of problems, namely responseshift bias and social desirability bias. ${ }^{84,85}$ The Implicit Association Test (IAT) can be adapted to evaluate whether those most affected by discrimination are willing to recognize and report it as such, thereby minimizing cognitive problems affecting self-report data. 86

\section{OPPORTUNITIES FOR USE OF MEASUREMENT}

Following the review of the metrics associated with systemic, interpersonal, and internalized racism, we have identified several gaps that can be addressed with a more robust measurement framework. Understanding the interplay between racism and health is not enough, however; as Nancy Krieger notes, "the reason to study how injustice harms health is not to prove that injustice is wrong, since it is, by definition...the reasons are to deepen understanding of how injustice shapes population health...and to generate evidence for accountability."53 To "generate evidence for accountability," as Krieger puts it, we have identified gaps in the literature, outlining the following list of opportunities for use of measurement, which is not about new measures, but, instead, using accurate measures consistently and mapping such measures to investments to become more accountable.

\section{Systemic Racism}

(1) Develop a baseline understanding of racial disparities across sectors in Ohio. One starting point would be the development of a "Disparity Report" for the State of Ohio, mirroring the initiative of the New York City Disparity Report, which includes indicators in education, economic security and mobility, health and wellbeing, and personal and community safety, with each metric segmented by race. 87 The Ohio Department of Health has put forth reports on disparities in infant mortality and pregnancy-related mortality caused by racism, ${ }^{88,89}$ but to share disparities in an actionable way, organizations and institutions should embrace the framework described herein to consider the many dimensions that contribute to such outcomes. Table 2 in the Appendix provides an example of a more comprehensive analysis that is possible with existing measures, presenting disparities in health outcomes alongside disparities in the built environment, economy, education, and criminal legal system, as it presents intermediaries between racism and metrics shown in Table 1. More work, however, is needed to incorporate aspects of structural racism in preparing health equity and anti-racism data reports. ${ }^{70,90,91}$

(2) Understand how existing algorithms contribute to racial bias, which sectors are affected, and other labels on which the algorithm can be trained to mitigate the effects of racial bias. Using the health system's algorithm for high-risk care management programs as a continued example, alternative label choices include avoidable costs (eg, emergency visits and hospitalizations), number of chronic conditions, and a combined health prediction with cost prediction, which can reduce racial bias by as much as $84 \%{ }^{50}$ Highlighting the importance of how an algorithm is trained is relevant beyond the health care sector. For instance, credit-scoring algorithms predict outcomes by income, a measure that reflects structural inequalities related to employment and salary. ${ }^{92}$ Similarly, hiring algorithms exhibit bias with respect to race and sex. ${ }^{93,94}$ Further research is needed on the data sources, such as claims data, that contribute to the racial bias in algorithms when cost prediction is used.

(3) Explore dimensions of ethnicity. To assess the extent of variation within racial and ethnic groups and identify which subgroups are most affected, researchers should collect more detailed ethnic data (eg, breaking down Hispanic into Cuban, Dominican, Mexican, and Puerto Rican). Further sampling questions regarding citizenship, voting rights, and place of birth of participants, their parents, and their grandparents will not only enable better understanding of ethnic diversity but also provide an opportunity to more precisely study how contemporary immigration policy adversely affects health. $28,95,96$

(4) Use new tools in policy analysis to quantify impact. Within policy analysis, there are ample opportunities to contribute because there is a lack of empirical evidence to identify which mechanisms of segregation-educational opportunity, labor market, or housing quality - should be tackled first, which would have the largest impact, and which is most likely to trigger ripple effects to other pathways on an individual's health. ${ }^{95}$ The development and deployment of a "Disparity Report" could help in this regard. To identify the proximal mechanisms that link segregation to health, data scientists and statisticians must leverage (a) new models that capture dynamic historical processes that influence each other over time at multiple levels of analysis to provide a new way of seeing and understanding persistent problems, and (b) new statistical techniques, such as instrumental variable (IV) analyses, to estimate the causal effects of segregation by reducing or eliminating bias related to selection and unmeasured confounding variables. ${ }^{97,98}$ 


\section{Interpersonal Racism}

There exist a few opportunities for health systems to assess how individual and systemic changes can promote the adoption of antiracism in care delivery.

(1) Capture a baseline measure of potential effects of interpersonal racism in health care. Quantitative and qualitative indicators should be considered, such as patient satisfaction with health services and perceived quality of care; trust in health system and professionals; communication and relationship with health service professionals; frequency of delaying, or simply not getting, health care; and visits and admissions to hospitals and emergency departments. ${ }^{74}$

(2) Evaluate how clinical organizations adhere to anti-racism efforts such as cultural competency standards. Although cultural competency has for many years been proposed to mitigate the effects of interpersonal racism in health care, more research has shown that structural competency in terms of changes at the health system level are needed to affect behavioral change. ${ }^{29}$ Baseline measures could provide better insight into the benefits of training in structural competency rather than cultural competency (or other existing standards of practice) as well as facilitate routine monitoring of progress in its institutional anti-racism agenda, much like Ohio State University Wexner Medical College has outlined, with its commitment to evaluate efforts and deliver annual anti-racism reports. ${ }^{90}$ The CLAS Standards require health care organizations to establish culturally and linguistically appropriate goals and policies that are incorporated into the organization's clinical operations, providing an early roadmap, but a more elaborate measurement framework is needed to evaluate performance against the standards and inform quick course correction if efforts do not result in systemic change. Organizations such as Multiethnic Advocates for Cultural Competence, ${ }^{99}$ which is a community expert in cultural competency training, would serve as an excellent partner in developing organizational and practice-based measures that align and/or expand on the CLAS standards. Ohio's COVID-19 Minority Health Strike Force Blueprint has also highlighted several strategies for dismantling racism through cultural and linguistic competency. 100

(3) Develop better methods of quantifying discrimination. Additional research is needed to determine optimal approaches for comprehensively measuring discrimination in all its dimensions, including chronicity, recurrence, severity, and duration. 95

\section{RECOMIMENDATIONS FOR APPLYING RACISM MEASUREMENT FRAMEWORK IN PRACTICE}

\section{Systemic Racism}

(1) Participate in community-based and community-engaged research and evaluation. Among academic centers, there is an even greater need for community partnerships and collaborations, evaluating interventions for (a) the extent to which they may be differentially effective across diverse subsets of the populations and (b) cost-effectiveness, but it is critically important that researchers engage with communities and build on their existing knowledge and insights by incorporating community members in all phases of research including study design, data collection, analysis, and dissemination. ${ }^{34,95,101}$ In Ohio, there are several organizations invested in addressing the $\mathrm{SDoH}$ and racism through effective interventions, as highlighted in Table 2 in the Appendix. These models need to be evaluated, disseminated, and adopted by others attempting to address complex problems. When pursuing community-engaged research, research budgets should take into account the need for translation resources and services as well as compensation for survey respondents. ${ }^{34}$

\section{Interpersonal Racism}

(1) Consider adoption of the Structural Vulnerability Assessment Tool. The Structural Vulnerability Assessment Tool operationalizes the concept of structural competency and provides a way to assess patients' nonmedical social needs, while minimizing the influences of provider bias.68 Importantly, the Structural Vulnerability Assessment Tool includes questions about discrimination, providing an opportunity for medical centers and health systems to assess discrimination without having to administer another survey or questionnaire to a subset of the patient population.

\section{Internalized Racism}

(1) Reconsider race as a variable in research. As a starting point, researchers must reconsider race as a mere "dummy variable,"102 taking into account their a priori assumptions of how race plays into the model as a way of recognizing potential biases, which is a critical component in the Public Health Critical Race Praxis (PHCRP) framework.1,27,34 The PHCRP contributes an ant-racism lexicon based on critical race theory (CRT) that avoids the repeated use of "vulnerable," a common euphemism embedded in public health literature that is used to soften, if not avoid, the discussion of racism. ${ }^{103,104}$

\section{CONCLUSION}

The COVID-19 pandemic, the deaths of George Floyd and Breonna Taylor among countless others, coupled with the resurgence of the Black Lives Matter movement, has advanced investments in anti-racism efforts, but it remains to be determined if the implementation of these efforts will result in meaningful change. ${ }^{105} \mathrm{~A}$ measurement framework is needed to understand the issue of racism more deeply, challenge the white racial framing by considering racism's many dimensions, ${ }^{27}$ and elucidate whether antiracism efforts are changing the pathways toward more equitable health access and outcomes. In this way, organizations and agencies can apply this framework to their own anti-racism agendas to differentiate what is working from what is not and to identify what can be generalized to other settings. This level of evaluation is needed to translate declarations of "racism as a public health emergency" into actions, advancing the pursuit of health equity in the state of Ohio. 
Table 1. Mapping the Metrics of Systemic Racism onto Social Determinants of Health and Health Impacts

\begin{tabular}{|c|c|c|c|c|}
\hline $\begin{array}{l}\text { Policy } \\
\text { Sector }\end{array}$ & Relevant Policy & Metrics & $\begin{array}{c}\text { Social } \\
\text { Determinants of } \\
\text { Health }\end{array}$ & Health Impact \\
\hline \multirow[t]{2}{*}{ Housing } & \multirow[t]{2}{*}{$\begin{array}{l}\text { Redlining } \\
\text { Homestead } \mathrm{Act}^{33}\end{array}$} & $\begin{array}{l}\text { Index of dissimilarity: proportion of } \\
\text { Blacks or Whites who would have } \\
\text { to move out of their neighborhood } \\
\text { to achieve an even distribution, or } \\
\text { complete integration }\end{array}$ & \multirow[t]{2}{*}{$\begin{array}{l}\text { Lower quality } \\
\text { housing and } \\
\text { schools }^{106} \\
\text { Food deserts } \\
\text { Environmental } \\
\text { racism }\end{array}$} & \multirow{2}{*}{$\begin{array}{l}\text { Reduced access to health services }{ }^{109} \\
\text { Segregated hospitals with lower quality } \\
\text { of care }^{108} \\
\text { Primary care shortage } \\
\text { Decreased utilization of services } \\
\text { Shortened life expectancy }{ }^{111} \\
\text { Higher risk of COVID-19 }\end{array}$} \\
\hline & & $\begin{array}{l}\text { Isolation: degree to which Blacks have } \\
\text { potential contact with non-Blacks }\end{array}$ & & \\
\hline $\begin{array}{l}\text { Criminal } \\
\text { Legal }\end{array}$ & $\begin{array}{l}\text { War on Drugs } \\
\text { Policing } \\
\text { Mass incarceration } \\
\text { Sentencing disparities } \\
\text { Mandatory minimums }\end{array}$ & $\begin{array}{l}\text { Proportions of Blacks to Whites who } \\
\text { were }{ }^{35,38} \text { : } \\
\text { incarcerated } \\
\text { disenfranchised felons } \\
\text { on death row }\end{array}$ & $\begin{array}{l}\text { Generational } \\
\text { poverty } \\
\text { Single-parent } \\
\text { households }\end{array}$ & $\begin{array}{l}\text { Black-White gaps in depressive } \\
\text { symptoms } \\
\text { Adverse childhood experiences (ACEs) } \\
\text { Elevated mortality risk }^{115} \\
\text { Higher community-level incidence of }^{114} \\
\text { HIV }^{115} \\
\text { Decreased utilization of health care }\end{array}$ \\
\hline \multirow[t]{3}{*}{ Economics } & \multirow[t]{3}{*}{$\begin{array}{l}\text { New Deal's Fair Labor } \\
\text { Standards Act of } 1938 \\
(\text { FLSA) } \\
\text { Wagner Act }^{44} \\
\text { Right-to-work laws }^{44}\end{array}$} & $\begin{array}{l}\text { Earnings rank gap: sex-specific } \\
\text { difference between a Black individual's } \\
\text { percentile in the Black earnings } \\
\text { distribution and the position in the } \\
\text { White earnings distribution }{ }^{45}\end{array}$ & \multirow{3}{*}{$\begin{array}{l}\text { Generational } \\
\text { poverty } \\
\text { Barriers to higher } \\
\text { education } \\
\text { Barriers to health } \\
\text { care access } \\
\text { Higher uninsured } \\
\text { rates }\end{array}$} & \multirow{3}{*}{$\begin{array}{l}\text { Lower self-reported health status (SRHS), } \\
\text { a measure correlated with objective } \\
\text { measures of health, including mortality } \\
\text { and functional decline }{ }^{54} \\
\text { Reduced cognitive functioning } \\
\text { Heightened cardiovasscular and } \\
\text { coronary mortality }^{54} \\
\text { Worsened psychological health that } \\
\text { is tied to greater exposure to } \\
\text { psychosocial job stressors and low } \\
\text { job control and support }\end{array}$} \\
\hline & & $\begin{array}{l}\text { Racial opportunity gap: sex-specific } \\
\text { difference in income percentile ranking } \\
\text { in adulthood between Black and White } \\
\text { children born to families at the same } \\
\text { income level in the same county }{ }^{42}\end{array}$ & & \\
\hline & & $\begin{array}{l}\text { Proportions of Blacks to Whites who } \text { wh }^{35,38} \\
\text { were employed } \\
\text { were in the labor force } \\
\text { were in executive or managerial } \\
\text { positions } \\
\text { were in professional specialties } \\
\text { had attained a bachelor's level } \\
\text { degree or higher }\end{array}$ & & \\
\hline Voting & $\begin{array}{l}\text { Voter Suppression Laws, } \\
\text { including }{ }^{36,37} \text { : } \\
\text { government-issued } \\
\text { photo ID require- } \\
\text { ments } \\
\text { citizenship laws } \\
\text { elimination of } \\
\text { same-day voter } \\
\text { registration } \\
\text { reductions of early and } \\
\text { absentee voting } \\
\text { days } \\
\text { restrictions on } \\
\text { restoration of voting } \\
\text { rights for felons } \\
\text { gerrymandering } \\
\text { voter purging }\end{array}$ & $\begin{array}{l}\text { Proportions of Blacks to Whites who }{ }^{38} \text { : } \\
\text { were registered to vote } \\
\text { actually voted } \\
\text { were elected to the state legislature }\end{array}$ & $\begin{array}{l}\text { Social isolation } \\
\text { Limited social }^{117} \\
\text { capital }^{117} \\
\text { Lower levels of }^{\text {education }} \\
\text { attainment }^{117} \\
\text { Lower income }^{117}\end{array}$ & $\begin{array}{l}\text { Lower self-rated health } \\
\text { Worsened psychological health tied to } \\
\text { increased allostatic load } \\
\text { Reduced life expectancy }\end{array}$ \\
\hline $\begin{array}{l}\text { Health } \\
\text { care }\end{array}$ & $\begin{array}{l}\text { Medicaid reimbursement } \\
\text { rates } \\
\text { Employing algorithms } \\
\text { that use cost prediction } \\
\text { as its metric } \\
\text { Hill-Burton Act } \\
\text { Gl Bill } \\
\text { Exclusion by American } \\
\text { Medical Association } \\
\text { Mel }\end{array}$ & $\begin{array}{l}\text { Proportions of physicians participating } \\
\text { in Medicaid by county racial } \\
\text { demographics } \\
\text { Illness burden at same level of } \\
\text { algorithm-predicted risk }\end{array}$ & $\begin{array}{l}\text { Restricted health } \\
\text { access } s^{46,47}\end{array}$ & $\begin{array}{l}\text { Reduced use of health services }{ }^{50,108,110} \\
\text { White patients receiving better quality of } \\
\text { care than Black patients } \\
\text { Under-enrollment of Black patients in } \\
\text { high risk care management programs }\end{array}$ \\
\hline
\end{tabular}

\section{ACKNOWLEDGMENTS}

We thank the team at Ohio State University's Center for Health Outcomes and Policy Evaluation Studies for supporting the development of the racism measurement framework.

\section{REFERENCES}

1. Ford CL, Airhihenbuwa CO. Critical race theory, race equity, and public health: toward antiracism praxis. Am J Public Health. 2010;100 (SUPPL. 1):693-698. https://doi.org/10.2105/AJPH.2009.171058 
2. Shavers VL, Fagan P, Jones D, et al. The state of research on racial/ ethnic discrimination in the receipt of health care. Am J Public Health. 2012;102(5):953-966. https://doi.org/10.2105/AJPH.2012.300773

3. Declarations of Racism as a Public Health Issue. American Public Health Association. Published 2020.

https://www.apha.org/topics-and-issues/health-equity/racism-andhealth/racism-declarations

4. Evans MK, Rosenbaum L, Malina D, Morrissey S, Rubin EJ. Diagnosing and treating systemic racism. N Engl J Med. 2020:1-2.

https://doi.org/10.1056/NEJMe2021693

5. Kovac M. Franklin County: "racism is a public health crisis." The Columbus Dispatch. Published May 14, 2020.

https://www.dispatch.com/news/20200514/franklin-countylsquoracism-is-public-health-crisisrsquo

6. Tyson P, Brown E, Brown M, et al. Resolution Declaring Racism a Public Health Crisis in Columbus. Columbus; 2020.

https://www.columbus.gov/racismresolution/

7. Brown M, O'Grady J, Boyce KL. Franklin County Commissioners Declaration of Racism as a Public Health Crisis. Franklin County; 2020. https://crms.franklincountyohio.gov/RMSWeb/pdfs/68146.FINAL Resolution_FCPH_DeclaredRacismPublicHealthCrisis.pdf

8. Roberts MW, Morrison KJ. Resolution No. 20-10. Columbus, OH; 2020.

9. Goist R. Akron declares racism a public health crisis, launches task force to develop five-year equity plan - cleveland.com. Cleveland.com. Published June 8, 2020. Accessed October 20, 2020.

https://www.cleveland.com/akron/2020/06/akron-declares-racisma-public-health-crisis-launches-task-force-to-develop-five-yearequity-plan.html

10. Weingartner T. Racism declared a public health crisis in Hamilton County | WOSU Radio. WOSU Public Media. Published July 16, 2020. Accessed October 20, 2020.

https://radio.wosu.org/post/racism-declared-public-health-crisishamilton-county\#stream/0

11. County commissioners declare racism a public health crisis. Montgomery County. Published June 16, 2020. Accessed October 20, 2020. https://www.mcohio.org/news_detail_T6_R485.php

12. Astolfi C. Cuyahoga County declares racism a public health crisis. Cleveland.com. Published July 7, 2020. Accessed October 20, 2020. https://www.cleveland.com/news/2020/07/cuyahoga-countydeclares-racism-a-public-health-crisis.html

13. Whaley N, Lavender R. Resolution No. 6512-20 Declaring Racism a Public Health Crisis in the City of Dayton, Ohio, and Declaring an Emergency. Dayton; 2020. Accessed October 20, 2020.

https://www.daytonohio.gov/DocumentCenter/View/9514/ Resolution-No-6512-20

14. Martin K. Lorain County commissioners declare racism "public health crisis." Morning Journal. Published June 17, 2020. Accessed October 20, 2020

https://www.morningjournal.com/news/lorain-county/loraincounty-commissioners-declare-racism-public-health-crisis/ article_ef4cc7f4-b0c4-11ea-ab19-fb8dbf5b25af.html

15. Mills E. Summit County declares racism a public health crisis. Beacon Journal. Published June 15, 2020. Accessed October 20, 2020. https://www.beaconjournal.com/story/news/politics/ county/2020/06/15/summit-county-declares-racism-public-healthcrisis/113396356/

16. Griffin BA, Jones BS, McCormack K, et al. Resolution No. 296-2020: An Emergency Resolution Declaring Racism a Public Health Crisis and Establishing a Working Group to Promote Racial Equity in the City of Cleveland. Cleveland; 2020.

https://cityofcleveland.legistar.com/LegislationDetail.aspx? ID=4348675\&GUID=32569022-4E96-4EDA-AF9F-398FE74D1179

17. Walliser-Wejebe M. Communities across the state declare racism as a public health crisis, the state considers it. Greater Ohio Policy Center. https://www.greaterohio.org/blog/2020/7/16/communities-acrossthe-state-declare-racism-as-a-public-health-crisis-the-state-considers - it

18. Thakur N, Lovinsky-Desir S, Bime C, Wisnivesky JP, Celedón JC. The structural and social determinants of the racial/ethnic disparities in the U.S. COVID-19 pandemic: what's our role? Am J Respir Crit Care Med. 2020;202(2):1-28. https://doi.org/10.1164/rccm.202005-1523PP

19. Wojcik O, Miller CE, Plough AL. Aligning health and social systems to promote population health, Well-Being, and Equity. Am J Public Health. 2020;110(2):176-177. https://doi.org/10.2105/AJPH.2020.305831

20. Hardeman RR, Medina EM, Boyd RW. Stolen breaths. $N$ Engl J Med. 2020;383:197-199. https://doi.org/10.1056/NEJMp2021072

21. Solar O, Irwin A. A Conceptual Framework for Action on the Social Determinants of Health. Social Determinants of Health Discussion Paper 2 (Policy and Practice). Geneva; 2010. https://www.who.int/sdhconference/resources/ ConceptualframeworkforactiononSDH_eng.pdf

22. Krieger N. Theories for social epidemiology in the 21st century: an ecosocial perspective. Int J Epidemiol. 2001;30:668-677. https://doi.org/10.1093/ije/30.4.668

23. Palmer RC, Ismond D, Rodriquez EJ, Kaufman JS. Social determinants of health: future directions for health disparities research. Am J Public Health. 2019;109(S1):S70-S71. https://doi.org/10.2105/AJPH.2019.304964

24. Kruse KM. How Segregation Caused Your Traffic Jam. The New York Times Magazine. August 2019. Accessed October 20, 2020. https://www.nytimes.com/interactive/2019/08/14/magazine/ traffic-atlanta-segregation.html

25. Nodjimbadem K. The Racial Segregation of American Cities Was Anything But Accidental. Smithsonian Magazine. May 2017. Accessed November 19, 2020.

https://www.smithsonianmag.com/history/how-federal-government -intentionally-racially-segregated-american-cities-180963494/

26. Ehlers CL, Gizer IR, Gilder DA, Ellingson JM, Yehuda R. Measuring historical trauma in an American Indian community sample: contributions of substance dependence, affective disorder, conduct disorder and PTSD. Drug Alcohol Depend. 2013;133(1):180-187. https://doi.org/10.1016/j.drugalcdep.2013.05.011

27. Hardeman RR, Karbeah J. Examining racism in health services research: a disciplinary self-critique. Health Serv Res. 2020;55(S2):777780.

https://doi.org/10.1111/1475-6773.13558 
28. Jones CP. Confronting institutionalized racism. Phylon. 2003;50(12):7-22.

https://doi.org/10.2307/4149999

29. Jones CP. Levels of racism: a theoretic framework and a gardener's tale. Am J Public Health. 2000;90:1212-1215. https://doi.org/10.2105/ajph.90.8.1212

30. Paradies Y, Ben J, Denson N, et al. Racism as a determinant of health: a systematic review and meta-analysis. PLoS One. 2015;10(9):1-48. https://doi.org/10.1371/journal.pone.0138511

31. Egede LE, Walker RJ. Structural racism, social risk factors, and Covid19 - a dangerous convergence for Black Americans. N EnglJ Med. 2020:1-3. https://doi.org/10.1056/NEJMp2023616

32. Collins CA, Williams DR. Segregation and Mortality: The deadly effects of racism. Sociol Forum. 1999;14(3):495-523. https://doi.org/10.1023/A:1021403820451

33. Canaday N, Reback C, Stowe K. Race and local knowledge: new evidence from the Southern Homestead Act. Rev Black Polit Econ. 2015;42(4):399-413. https://doi.org/10.1007/s12114-015-9212-7

34. Brown KS, Kijakazi K, Runes C, Turner MA. Confronting structural racism in research and policy analysis. Urban Institute. 2019;February(November 2018):1-16. https://www.urban.org/sites/default/files/publication/99852/ confronting_structural_racism_in_research_and_policy_analysis_0.pdf

35. Groos M, Wallace M, Hardeman R, Theall K. Measuring inequity: a systematic review of methods used to quantify structural racism. $J$ Health Dispar Res Pract. 2018;11(2):13.

https://digitalscholarship.unlv.edu/cgi/viewcontent.cgi? article $=1792 \&$ context $=$ jhdrp

36. Block the Vote: Voter Suppression in 2020. American Civil Liberties Union (ACLU). Published 2020.

https://www.aclu.org/news/civil-liberties/block-the-vote-votersuppression-in-2020/

37. Combs BH. Black (and brown) bodies out of place: towards a theoretical understanding of systematic voter suppression in the United States. Crit Sociol. 2016;42(4-5):535-549. https://doi.org/10.1177/0896920514563089

38. Lukachko A, Hatzenbuehler ML, Keyes KM. Structural racism and myocardial infarction. Soc Sci Med. 2014;103:42-50.

https://doi.org/10.1016/j.socscimed.2013.07.021

39. Boen CE. Criminal justice contacts and psychophysiological functioning in early adulthood: health Inequality in the carceral state. J Health Soc Behav. 2020:1-17.

https://doi.org/10.1177/0022146520936208

40. Phillips S, Marceau J. Whom the state kills. Harv Civ Rights-Civil Lib Law Rev. 2020;55.

https://harvardcrcl.org/wp-content/uploads/ sites/10/2020/08/08.10.2020-Phillips-Marceau-For-Website.pdf

41. The Death Lottery: How Race and Geography Determine Who Goes to Ohio's Death Row. Cincinnati, OH; 2014.

http://www.otse.org/wp-content/uploads/2014/04/OTSE-ReportThe-Death-Lottery.pdf

42. O’Brien R, Neman T, Seltzer N, Evans L, Venkataramani A. Structural racism, economic opportunity and racial health disparities: evidence from U.S. counties. SSM Popul Health. 2020;11:100564.

https://doi.org/10.1016/j.ssmph.2020.100564

43. Malat J, Mayorga-Gallo S, Williams DR. The effects of whiteness on the health of whites in the USA. Soc Sci Med. 2018;199:148-156.

https://doi.org/10.1016/j.socscimed.2017.06.034

44. Solomon D, Maxwell C, Castro A. Systematic Inequality and Economic Opportunity. Washington, D.C.; 2019.

https://www.americanprogress.org/issues/race/

reports/2019/08/07/472910/systematic-inequality-economicopportunity/

45. Bayer P, Charles KK. Divergent paths: A new perspective on earnings differences between black and white men since 1940. Q JEcon. 2018;133(3):1459-1501. https://doi.org/10.1093/QJE/QJY003

46. Cunningham P, May J. Medicaid Patients Increasingly Concentrated among Physicians: Results from the Community Tracking Study. Washington, D.C.; 2006. http://www.hschange.org/CONTENT/866/866.pdf

47. Greene J, Blustein J, Weitzman BC. Race, segregation, and physicians' participation in Medicaid. Milbank Q. 2006;84(2):239-272.

https://doi.org/10.1111/j.1468-0009.2006.00447.x

48. Discrimination. Healthy People. Published 2020.

https://www.healthypeople.gov/2020/topics-objectives/topic/social -determinants-health/interventions-resources/discrimination

49. 2015 National Healthcare Quality and Disparities Report and 5th Anniversary Update on the National Quality Strategy. Rockville, MD; 2016.

http://www.ahrq.gov/sites/default/files/wysiwyg/research/ findings/nhqrdr/nhqdr15/2015nhqdr.pdf

50. Obermeyer Z, Powers B, Vogeli C, Mullainathan S. Dissecting racial bias in an algorithm used to manage the health of populations. Science. 2019;366(6464):447-453.

https://doi.org/10.1126/science.aax2342

51. Kakani P, Chandra A, Mullainathan S, Obermeyer Z. Allocation of COVID-19 relief funding to disproportionately Black counties. JAMA. 2020:17-19.

https://doi.org/10.1001/jama.2020.14978

52. Gray DM, Joseph JJ, Olayiwola JN. Strategies for digital care of vulnerable patients in a COVID-19 world-keeping in touch. JAMA Health Forum. 2020;1(6):e200734-e200734. https://doi.org/10.1001/JAMAHEALTHFORUM.2020.0734

53. Krieger N. Measures of racism, sexism, heterosexism, and gender binarism for health equity research: from structural injustice to embodied harm—an ecosocial analysis. Annu Rev Public Health. 2020;41 (1):37-62. https://doi.org/10.1146/annurev-publhealth-040119-094017

54. McCluney CL, Schmitz LL, Hicken MT, Sonnega A. Structural racism in the workplace: does perception matter for health inequalities? Soc Sci Med. 2018;199:106-114. https://doi.org/10.1016/j.socscimed.2017.05.039

55. Kang SK, DeCelles KA, Tilcsik A, Jun S. Whitened résumés: race and self-presentation in the labor market. Adm Sci Q. 2016;61(3):469-502. https://doi.org/10.1177/0001839216639577

56. Agan A, Starr S. Ban the box, criminal records, and racial discrimination: a field experiment. Q JEcon. 2018;133(1):191-235. https://doi.org/10.1093/qje/qjx028 
57. D'Anna LH, Hansen M, Mull B, Canjura C, Lee E, Sumstine S. Social discrimination and health care: a multidimensional framework of experiences among a low-income multiethnic sample. Soc Work Public Health. 2018;33(3):187-201.

https://doi.org/10.1080/19371918.2018.1434584

58. Ryn M van, Fu SS. Paved with good intentions: do public health and human service providers contribute to racial/ethnic disparities in health? Am J Public Health. 2003;93(2):248-255. https://doi.org/10.2105/ajph.93.2.248

59. McGuire TG, Miranda J. New evidence regarding racial and ethnic disparities in mental health care: policy implications. Health Affairs. 2008;27(2):393-403. https://doi.org/10.1377/hlthaff.27.2.393

60. Alhusen JL, Bower K, Epstein E, Sharps P. Racial discrimination and adverse birth outcomes: an integrative review. JMidwifery Womens Health. 2016;61(6):707-720.

https://doi.org/10.1111/jmwh.12490

61. Davis DA. Obstetric Racism: The racial politics of pregnancy, labor, and birthing. Medical Anthropology: Cross Cultural Studies in Health and Illness. 2019;38(7):560-573.

https://doi.org/10.1080/01459740.2018.1549389

62. Rosenthal L, Lobel M. Gendered racism and the sexual and reproductive health of Black and Latina Women. Ethn Health. 2020;25(3):367392.

https://doi.org/10.1080/13557858.2018.1439896

63. Elliott AM, Alexander SC, Mescher CA, Mohan D, Barnato AE. Differences in physicians' verbal and nonverbal communication with black and white patients at the end of life. J Pain Symptom Manage. 2016;51 (1):1-8. https://doi.org/10.1016/j.jpainsymman.2015.07.008

64. Lurie N. Health disparities - Less talk, more action. $N$ Engl J Med. 2005;353(7):727-729.

https://doi.org/10.1056/NEJMe058143

65. Bell S. Racism: treating a socially transmitted disease. American Academy of Pediatrics. Published 2019.

https://services.aap.org/en/news-room/aap-voices/racism-treatinga-socially-transmitted-disease/

66. Kalata M, Kalata K, Yen H, Khorshid A, Davis T, Meredith J. Community perspectives on the racial disparity in perinatal outcomes. J Matern Fetal Neonatal Med. 2020:1-6. https://doi.org/10.1080/14767058.2020.1786525

67. Narayan MC. The national standards for culturally and linguistically appropriate service in health care. Care Manag J. 2001;3(2):77-83. https://doi.org/10.1891/1521-0987.3.2.77

68. Bourgois P, Holmes SM, Sue K, Quesada J. Structural vulnerability: operationalizing the concept to address health disparities in clinical care. Acad Med. 2017;92(3):299-307.

https://doi.org/10.1097/acm.0000000000001294

69. Tervalon M, Murray-García J. Cultural humility versus cultural competence: a critical distinction in defining physician training outcomes in multicultural education. J Health Care Poor Underserved. 1998;9

(2):117-125.

https://doi.org/10.1353/hpu.2010.0233

70. Gray DM, Joseph JJ, Glover AR, Olayiwola JN. How academia should respond to racism. Nat Rev Gastroenterol Hepatol. 2020:1-2. https://doi.org/10.1038/s41575-020-0349-x
71. Cahn PS. How interprofessional collaborative practice can help dismantle systemic racism. J Interprof Care. 2020;34(4):431-434. https://doi.org/10.1080/13561820.2020.1790224

72. Neff J, Holmes SM, Knight KR, et al. Structural competency: curriculum for medical students, residents, and interprofessional teams on the structural factors that produce health disparities. MedEdPORTAL. 2020;16:10888. https://doi.org/10.15766/mep_2374-8265.10888

73. Cuffee YL, Hargraves JL, Rosal M, et al. Reported racial discrimination, trust in physicians, and medication adherence among inner-city African Americans with hypertension. Am J Public Health. 2013;103 (11):55-62. https://doi.org/10.2105/AJPH.2013.301554

74. Ben J, Cormack D, Harris R, Paradies Y. Racism and health service utilisation: a systematic review and meta-analysis. PLoS One. 2017;12 (12):1-22.

https://doi.org/10.1371/journal.pone.0189900

75. Paradies YC. Defining, conceptualizing and characterizing racism in health research. Crit Public Health. 2006;16(2):143-157. https://doi.org/10.1080/09581590600828881

76. Berman G, Paradies Y. Racism, disadvantage and multiculturalism: towards effective anti-racist praxis. Ethn Racial Stud. 2010;33(2):214 -232 . https://doi.org/10.1080/01419870802302272

77. Krieger N. Embodiment: A conceptual glossary for epidemiology. $J$ Epidemiol Community Health. 2005;59(5):350-355. https://doi.org/10.1136/jech.2004.024562

78. Geronimus AT, Hicken M, Keene D, Bound J. "Weathering” and age patterns of allostatic load scores among blacks and whites in the United States. Am J Public Health. 2006;96(5):826-833. https://doi.org/10.2105/AJPH.2004.060749

79. Peek ME, Sayad J v., Markwardt R. Fear, fatalism and breast cancer screening in low-income African-American women: the role of clinicians and the health care system. J Gen Intern Med. 2008;23(11):1847 -1853 . https://doi.org/10.1007/s11606-008-0756-0

80. Williams DR. Measuring discrimination resource. J Health Psychol. 1997;2(3):335-351.

https://scholar.harvard.edu/files/davidrwilliams/files/ measuring_discrimination_resource_june_2016.pdf

81. Atkins R. Instruments measuring perceived racism/racial discrimination: review and critique of factor analytic techniques. Int $J$ Health Serv. 2014;44(4):711-734. https://doi.org/10.2190/HS.44.4.c

82. McNeilly M, Anderson N, Armstead C, et al. The perceived racism scale: a multidimensional assessment of the experience of white racism among African Americans. Ethn Dis. 1996;6(1-2):154-166. https://pubmed.ncbi.nlm.nih.gov/8882844/

83. Krieger N. Racial and gender discrimination: risk factors for high blood pressure? Soc Sci Med. 1990;30(12):1273-1281. https://doi.org/10.1016/0277-9536(90)90307-E

84. Rosenman R, Tennekoon V, Hill LG. Measuring bias in self-reported data. Int J Behav Healthc Res. 2011;2(4):320. https://doi.org/10.1504/ijbhr.2011.043414 
85. Latkin CA, Edwards C, Davey-Rothwell MA, Tobin KE. The relationship between social desirability bias and self-reports of health, substance use, and social network factors among urban substance users in Baltimore, Maryland. Addict Behav. 2017;73:133-136.

https://doi.org/10.1016/j.addbeh.2017.05.005

86. Krieger N. Discrimination and health inequities. In: Berkman LF, Kawachi I, Glymour MM, eds. Social Epidemiology (2nd Edition). New York: Oxford University Press; 2014.

https://doi.org/10.1093/med/9780195377903.003.0003

87. Center for Innovation through Data Intelligence. Disparity Report. New York; 2016.

http://bma.issuelab.org/resources/24145/24145.pdf

88. Oza-Frank R, Conrey EJ, Davis A, et al. Snapshot of Racial Disparities in Pregnancy-Related Deaths in Ohio 2008-2016. Columbus, OH; 2020.

https://odh.ohio.gov/wps/portal/gov/odh/know-our-programs/ pregnancy-associated-mortality-review/resources/racial-disparities

89. Oza-Frank R, Johnson T, Arendt A, et al. 2018 Infant Mortality Annual Report. Columbus, $\mathrm{OH} ; 2020$.

https://odh.ohio.gov/wps/portal/gov/odh/know-our-programs/ infant-and-fetal-mortality/reports/2018-ohio-infant-mortality-report

90. Anti-Racism Initiatives: Improving health equity through anti-racism efforts. The Ohio State University Wexner Medical Center. Published 2020.

https://wexnermedical.osu.edu/about-us/anti-racism-initiative

91. Wexner Medical Center and Health Science Colleges: Action Plan. The Ohio State University Wexner Medical Center. Published 2020.

https://wexnermedical.osu.edu/-/media/files/wexnermedical/about -us/anti-racism/actionplan.pdf

92. Hurley M, Adebayo J. Credit Scoring in the Era of Big Data. Yale Journal of Law and Technology. 2017;18(1):148-216.

https://digitalcommons.law.yale.edu/yjolt/vol18/iss1/5

93. Fink J. Gender sidelining and the problem of unactionable discrimination. Stanford Law Pol Rev. 2018;29(1):58-106.

https://www-cdn.law.stanford.edu/wp-content/

uploads/2018/03/29.1_Fink_57-106.pdf

94. Ajunwa I. The paradox of automation as anti-bias intervention.

Cardozo Law Rev. 2020;41:1-55.

https://doi.org/10.2139/ssrn.2746078

95. Williams DR, Lawrence JA, Davis BA. Racism and health: evidence and needed research. Annu Rev Public Health. 2019;40(1):105-125. https://doi.org/10.1146/annurev-publhealth-040218-043750

96. Gee GC, Ford CL. Structural racism and health inequities: old Issues, new directions. Du Bois Rev. 2011;8(1):115-132. https://doi.org/10.1017/S1742058X11000130

97. White K, Borrell LN. Racial/ethnic residential segregation: framing the context of health risk and health disparities. Health Place. 2011;17 (2):438-448. https://doi.org/10.1016/j.healthplace.2010.12.002

98. Diez Roux AV. Complex systems thinking and current impasses in health disparities research. Am J Public Health. 2011;101(9):16271634.

https://doi.org/10.2105/AJPH.2011.300149

99. Multiethnic Advocates for Cultural Competence. http://www.maccinc.net/overview
100. Aly R, McGee AR, Stevens AB, et al. COVID-19 Ohio Minority Health Strike Force Blueprint. Columbus, $\mathrm{OH} ; 2020$.

https://coronavirus.ohio.gov/static/MHSF/MHSF-Blueprint.pdf

101. Fullilove MT, Green LL, Hernández-Cordero LJ, Fullilove RE. Obvious and not-so-obvious strategies to disseminate research. Health Promot Pract. 2006;7(3):306-311. https://doi.org/10.1177/1524839906289377

102. LaVeist TA. Beyond dummy variables and sample selection: what health services researchers ought to know about race as a variable. Health Serv Res. 1994;29(1):1-16. https://www.ncbi.nlm.nih.gov/pmc/articles/PMC1069985/

103. Avila CJ. "Vulnerable" is a public health euphemism we need to stop using. The Incidental Economist. Published 2020. https://theincidentaleconomist.com/wordpress/vulnerable-is-apublic-health-euphemism-we-need-to-stop-using/

104. Ford CL, Airhihenbuwa CO. The public health critical race methodology: praxis for antiracism research. Soc Sci Med.2010;71(8):13901398.

https://doi.org/10.1016/j.socscimed.2010.07.030

105. Herndon AW. Are Racial Attitudes Really Changing? Some Black Activists Are Skeptical. The New York Times. Published August 11, 2020. https://www.nytimes.com/2020/08/11/us/politics/black-livesmatter-chicago-roseland.html?searchResultPosition=65

106. Matthew DB, Rodrigue E, Reeves RV. Time for Justice: Tackling Race Inequalities in Health and Housing. Washington, D.C.; 2016. https://www.brookings.edu/research/time-for-justice-tackling-raceinequalities-in-health-and-housing/

107. Bower KM, Thorpe RJ Jr, Rohde C, Gaskin DJ. The intersection of neighborhood racial segregation, poverty, and urbanicity and its impact on food store availability in the United States. Prev Med. 2014 Jan;58:33-9.

https://doi.org/10.1016/j.ypmed.2013.10.010

108. Arcaya MC, Schnake-Mahl A. Health in the segregated city. NYU Furman Center. Published 2017.

https://furmancenter.org/research/iri/essay/health-in-thesegregated-city

109. Goedel WC, Shapiro A, Cerdá M, Tsai JW, Hadland SE, Marshall BDL. Association of racial/ethnic segregation with treatment capacity for opioid use disorder in counties in the United States. JAMA Network Open. 2020;3(4):e203711.

https://doi.org/10.1001/jamanetworkopen.2020.3711

110. Gaskin DJ, Dinwiddie GY, Chan KS, McCleary R. Residential segregation and disparities in health care services utilization. Med Care Res Rev. 2012 Apr;69(2):158-175. https://doi.org/10.1177/1077558711420263

111. Weiler A. Why 50-year-old housing practices could be linked to poor health outcomes today. Public Health Insider. Published 2016. Accessed October 26, 2020.

https://publichealthinsider.com/2016/07/21/why-50-year-oldhousing-practices-could-be-linked-to-poor-health-outcomes-today/

112. Richardson J, Meier HCS, Mitchell BC, Edlebi J, Lynch E. The Lasting Impact of Historic "Redlining" on Neighborhood Health: Higher Prevalence of COVID-19 Risk Factors. Washington, D.C.; 2020. https://ncrc.org/holc-health/ 
113. Bobo LD, Thompson V. Unfair by design: the war on drugs, race, and the legitimacy of the criminal justice system. Social Research. 2006;73

(2):445-472.

https://www.brown.edu/Departments/Economics/Faculty/

Glenn_Loury/louryhomepage/teaching/Ec\%20222/

Bobo_Thompson_2006.pdf

114. Turney K. Adverse childhood experiences among children of incarcerated parents. Child Youth Serv Rev. 2018;89:218-225.

https://doi.org/10.1016/j.childyouth.2018.04.033

115. Wildeman C, Wang EA. Mass incarceration, public health, and widening inequality in the USA. Lancet. 2017;389(10077):1464-1474. https://doi.org/10.1016/S0140-6736(17)30259-3

116. Frank JW, Wang EA, Nunez-Smith M, Lee H, Comfort M. Discrimination based on criminal record and healthcare utilization among men recently released from prison: a descriptive study. Health Justice. 2014;2(1):6.

https://doi.org/10.1186/2194-7899-2-6

117. Dubowitz T, Nelson C, Weilant S, et al. Factors related to health civic engagement: results from the 2018 National Survey of Health Attitudes to understand progress towards a culture of health. BMC Public Health. 2020;20(1):635. https://doi.org/10.1186/s12889-020-08507-w

118. Blakely TA, Kennedy BP, Kawachi I. Socioeconomic inequality in voting participation and self-rated health. Am J Public Health. 2001;91 (1):99-104. https://doi.org/10.2105/AJPH.91.1.99

119. Purtle J. Felon disenfranchisement in the United States: a health equity perspective. Am J Public Health. 2013;103(4):632-637. https://doi.org/10.2105/AJPH.2012.300933

120. Latner M. Our Unhealthy Democracy: How Voting Restrictions Harm Public Health-and What We Can Do About It; 2019. Accessed October 26, 2020.

www.ucsusa.org/resources/our-unhealthy-democracy

121. Interlandi J. Why Doesn't America Have Universal Health Care? One Word: Race. The New York Times Magazine. Published August 14, 2019. Accessed October 27, 2020.

https://www.nytimes.com/interactive/2019/08/14/magazine/ universal-health-care-racism.html

122. Ohio Pregnancy Assessment Survey (OPAS). Columbus, OH; 2018. https://odh.ohio.gov/wps/portal/gov/odh/know-our-programs/ ohio-pregnancy-assessment-survey-opas/resources/2018-opasdatabook

123. America's Health Rankings Annual Report. United Health Foundation. Published 2019.

https://www.americashealthrankings.org/explore/annual/measure/ birthweight/state/OH

124. Revisiting the Silent Crisis: An Ohio Human Services Data Warehouse Report. Columbus, OH; 2018.

https://www.ohiohome.org/news/documents/HMIS-2017Update.pdf

125. Ohio Housing Needs Assessment: Technical Supplement to the Fiscal Year 2019 Annual Plan. Columbus, OH; 2019.

https://ohiohome.org/hna-20/executivesummary-hna.aspx

126. Gordon C, Hanauer A. Race in the Heartland.; 2019.

https://www.policymattersohio.org/research-policy/fair-economy/ work-wages/race-in-the-heartland-ohio-in-focus
127. Ohio Early Childhood Race and Rural Equity Report. Columbus, OH; 2018.

https://www.groundworkohio.org/equityreport

128. Schweizer VJ. Food Insufficiency Among Ohio's Children, 2016-2017. Bowling Green, OH; 2019.

https://www.bgsu.edu/content/dam/BGSU/college-of-arts-andsciences/center-for-family-and-demographic-research/documents/ OPN/Ohio-Population-News-2019-Food-Insecurity-June-v2.pdf

129. Sleesman J, Sobotka H. Ohio 2017 Behavioral Risk Factor Surveillance System (BRFSS) Annual Report. Columbus, OH; 2017.

https://odh.ohio.gov/wps/portal/gov/odh/know-our-programs/ chronic-disease/data-publications/ohio-2017-brfss-annual-report

130. 2019 Online State Health Assessment. Accessed October 26, 2020. https://odh.ohio.gov/wps/portal/gov/odh/explore-data-and-stats/ interactive-applications/2019-Online-State-Health-Assessment

131. Ohio Youth Risk Behavior Survey (YRBS). Columbus, OH; 2019. https://odh.ohio.gov/wps/portal/gov/odh/know-our-programs/ Youth-Risk-Behavior-Survey/High-School-Data

132. Cauchon D. Special Report: Race and Overdose in Ohio. Harm Reduction Ohio. https://www.harmreductionohio.org/race-and-overdose-in-ohio/

133. Suicide Demographics and Trends, Ohio, 2018. Columbus, $\mathrm{OH}$. https://odh.ohio.gov/wps/portal/gov/odh/know-our-programs/ violence-injury-prevention-program/media/suicide-demographicstrends-ohio-2018

134. Ohio Adolescent Reproductive Health Facts. U.S. Department of Health and Human Services (HHS), Office of Population Affairs. Published 2016.

https://www.hhs.gov/ash/oah/facts-and-stats/national-and-statedata-sheets/adolescent-reproductive-health/ohio/index.html

135. Population Data For Calculating Rates. Ohio Department of Health. Published 2020.

http://publicapps.odh.ohio.gov/EDW/DataBrowser/Browse/ Population

136. Wilson V. Black Unemployment Is at Least Twice as High as White Unemployment at the National Level and in 14 States and the District of Columbia. Washington, D.C.; 2019.

https://www.epi.org/publication/valerie-figures-stateunemployment-by-race/

137. Larrick D. The Ohio Poverty Report. Columbus, OH; 2019. https://www.development.ohio.gov/files/research/P7005.pdf

138. Aly R, Dorn SB, McGee AR, Stevens AB, Sustersic R. Ohio 2016 State Health Assessment. Columbus, OH; 2016. https://lucascountyhealth.com/wp-content/uploads/2017/03/StateHealth-Assessment-8-4-2016.pdf

139. Durnan J, Harvell S. Data Snapshot of Youth Incarceration in Ohio. Washington, D.C.; 2020.

https://www.urban.org/sites/default/files/publication/102218/ data-snapshot-of-youth-incarceration-in-ohio_0.pdf

140. State-by-State Data. The Sentencing Project. Published 2019. https://www.sentencingproject.org/the-facts/\#map

141. Racial Demographics. Death Penalty Information Center. Published 2020.

https://deathpenaltyinfo.org/death-row/overview/demographics 
APPENDIX Table 2. Landscape of Disparities Caused by Racism in Ohio and Opportunities for Community-Based Intervention

\begin{tabular}{|c|c|c|c|c|}
\hline Indicator & $\begin{array}{l}\text { Non-Hispanic } \\
\text { White }\end{array}$ & $\begin{array}{l}\text { Non-Hispanic } \\
\text { Black }\end{array}$ & $\begin{array}{l}\text { Rate Ratio } \\
\text { (Black v. } \\
\text { White) }\end{array}$ & $\begin{array}{l}\text { Examples of Ohio Organizations \& } \\
\text { Initiatives Addressing Indicator with } \\
\text { Racial Equity Lens }\end{array}$ \\
\hline \multicolumn{5}{|l|}{ Maternal \& Infant Health } \\
\hline No Prenatal Care ${ }^{122}$ & $8.0 \%$ & $19.5 \%$ & 2.4 & \multirow{5}{*}{$\begin{array}{l}\text { CelebrateOne; First Year Cleveland; } \\
\text { Cradle Cincinnati; Birthing Beautiful } \\
\text { Communities }\end{array}$} \\
\hline Preterm Birth ${ }^{123}$ & $9.4 \%$ & $14.4 \%$ & 1.5 & \\
\hline Low Birthweight $^{123}$ & $7.3 \%$ & $14.3 \%$ & 2.0 & \\
\hline Infant Mortality ${ }^{89}$ (per 1,000 live births) & 5.4 deaths & 13.9 deaths & 2.6 & \\
\hline Maternal Mortality ${ }^{88}$ (per 100,000 births) & 11.5 deaths & 29.5 deaths & 2.6 & \\
\hline \multicolumn{4}{|l|}{ Built Environment } & \multirow{4}{*}{$\begin{array}{l}\text { Affordable Housing Alliance of Central } \\
\text { Ohio; Homeless Families Foundation; } \\
\text { Coalition on Homelessness and } \\
\text { Housing in Ohio; Bessie's Angels; } \\
\text { YWCA; United Way; Greater Cincinnati } \\
\text { Homeless Coalition }\end{array}$} \\
\hline Homelessness ${ }^{124}$ & $45.0 \%$ & $49.5 \%$ & 1.1 & \\
\hline Housing Instability ${ }^{125}$ & $43.5 \%$ & $54.9 \%$ & 1.3 & \\
\hline No Home Ownership ${ }^{126}$ & $28.1 \%$ & $63.9 \%$ & 2.3 & \\
\hline \multicolumn{5}{|l|}{ Early Childhood } \\
\hline Not Kindergarten Ready & $53.0 \%$ & $76.1 \%$ & 1.4 & \multirow{9}{*}{$\begin{array}{l}\text { Family and Children First Council; } \\
\text { Action for Children; Columbus Early } \\
\text { Learning Centers; Tamir Rice } \\
\text { Foundation; United Way }\end{array}$} \\
\hline Not at $3^{\text {rd }}$ Grade Reading ${ }^{127}$ & $28.0 \%$ & $61.0 \%$ & 2.2 & \\
\hline $3^{\text {rd }}$ Grade Suspensions \& Expulsions ${ }^{127}$ & $5.1 \%$ & $45.1 \%$ & 8.8 & \\
\hline Food Insufficiency ${ }^{128}$ & $5.0 \%$ & $22.0 \%$ & 4.4 & \\
\hline Physical Inactivity ${ }^{129}$ & $82.0 \%$ & $81.3 \%$ & 1.0 & \\
\hline Incomplete Vaccinations ${ }^{123}$ & $34.6 \%$ & $39.8 \%$ & 1.2 & \\
\hline Childhood Poverty ${ }^{127}$ & $18.2 \%$ & $53.9 \%$ & 3.0 & \\
\hline Adverse Childhood Experiences (ACEs) ${ }^{127}$ & $40.0 \%$ & $61.0 \%$ & 1.5 & \\
\hline Childhood Asthma ${ }^{130}$ & $6.3 \%$ & $17.2 \%$ & 2.7 & \\
\hline \multicolumn{5}{|l|}{ Mental Health } \\
\hline Substance Use in Middle School ${ }^{131}$ & $8.9 \%$ & $17.5 \%$ & 2.0 & \multirow{5}{*}{$\begin{array}{l}\text { Urban League; Safe Point; Harm } \\
\text { Reduction Ohio; Urban Minority } \\
\text { Alcoholism and Drug Abuse Outreach } \\
\text { Program of Franklin County; Big } \\
\text { Brother Big Sister; Peel Dem Layers } \\
\text { Back; Ohio Organizing Collaborative }\end{array}$} \\
\hline Substance Use in High School ${ }^{131}$ & $8.9 \%$ & $23.5 \%$ & 2.6 & \\
\hline Overdose Mortality ${ }^{132}$ & $\begin{array}{l}33.4 \text { deaths per } \\
100,000 \text { residents }\end{array}$ & $\begin{array}{l}37.6 \text { deaths per } \\
100,000 \text { residents }\end{array}$ & 1.1 & \\
\hline Depression ${ }^{129}$ & $23.3 \%$ & $18.1 \%$ & 0.8 & \\
\hline Suicide ${ }^{133}$ & $\begin{array}{l}16.7 \text { deaths per } \\
100,000\end{array}$ & $\begin{array}{l}9.8 \text { deaths per } \\
100,000\end{array}$ & 0.6 & \\
\hline \multicolumn{5}{|l|}{ Reproductive Health } \\
\hline Unintended Pregnancy ${ }^{122}$ & $21.3 \%$ & $40.7 \%$ & 1.9 & \multirow{2}{*}{$\begin{array}{l}\text { Planned Parenthood; Preterm; New } \\
\text { Voices Cleveland }\end{array}$} \\
\hline Teenage Pregnancy ${ }^{134,135}$ & $\begin{array}{l}17.6 \text { per } 1,000 \\
\text { women aged } 15-19\end{array}$ & $\begin{array}{l}39.5 \text { per } 1,000 \\
\text { women aged } 15-19\end{array}$ & 2.2 & \\
\hline \multicolumn{4}{|l|}{ Education Outcomes } & \multirow{3}{*}{$\begin{array}{l}\text { Ohio Gap Closers; Urban League; Unit- } \\
\text { ed Way; Ohio Organizing Collabora- } \\
\text { tive }\end{array}$} \\
\hline No High School Diploma ${ }^{127}$ & $12.1 \%$ & $31.9 \%$ & 2.6 & \\
\hline No Bachelor's Degree ${ }^{127}$ & $72.4 \%$ & $83.9 \%$ & 1.2 & \\
\hline \multicolumn{5}{|l|}{ Labor \& Economy } \\
\hline Household Income ${ }^{126}$ & $\$ 56,395$ & $\$ 30,575$ & $\mathrm{~N} / \mathrm{A}$ & \multirow{3}{*}{$\begin{array}{l}\text { Ethiopian Tewahedo Social Services; } \\
\text { Urban League; 1,000 Ties; United Way; } \\
\text { Mortar }\end{array}$} \\
\hline Unemployment Rate ${ }^{136}$ & $4.3 \%$ & $6.9 \%$ & 1.6 & \\
\hline Poverty Rate ${ }^{137}$ & $10.7 \%$ & $28.8 \%$ & 2.7 & \\
\hline \multicolumn{5}{|l|}{ Health \& Disease $^{130}$} \\
\hline $\begin{array}{l}\text { Heart Disease Mortality Rate (per 100,000 } \\
\text { people) }\end{array}$ & 185.6 deaths & 211.8 deaths & 1.1 & \multirow{6}{*}{$\begin{array}{l}\text { Healthcare Collaborative of Greater } \\
\text { Columbus; Northeast Ohio Black } \\
\text { Health Coalition; Sisters of Charity } \\
\text { Foundation }\end{array}$} \\
\hline Stroke Mortality Rate (per 100,000 people) & 42.2 deaths & 51.6 deaths & 1.2 & \\
\hline Diabetes Mortality Rate (per 100,000 people) & 23.6 deaths & 41.2 deaths & 1.7 & \\
\hline Cancer Mortality Rate (per 100,000 people) & 176.3 deaths & 196.5 deaths & 1.1 & \\
\hline $\begin{array}{l}\text { Kidney Disease Mortality Rate (per 100,000 } \\
\text { people) }\end{array}$ & 13.5 deaths & 29.6 deaths & 2.2 & \\
\hline Life Expectancy ${ }^{138}$ & 78.1 years & 73.9 years & $\mathrm{N} / \mathrm{A}$ & \\
\hline \multicolumn{5}{|l|}{ Criminal Legal System } \\
\hline $\begin{array}{l}\text { Youth Incarcerated in Juvenile Correctional } \\
\text { Facilities (JCFs) }\end{array}$ & $33.1 \%$ & $55.6 \%$ & 1.7 & \multirow{3}{*}{$\begin{array}{l}\text { Intercommunity Justice and Peace } \\
\text { Center; Ohio Justice and Policy } \\
\text { Center; People's Justice Project; } \\
\text { Broken Chains Ministry; Ohio } \\
\text { Organizing Collaborative }\end{array}$} \\
\hline Imprisonment Rate ${ }^{140}$ & 289 per 100,000 & 1,625 per 100,000 & 5.6 & \\
\hline Death Row ${ }^{141}$ & $\begin{array}{l}40.4 \% \text { ( } 57 \text { of } 141 \\
\text { inmates on death } \\
\text { row) }\end{array}$ & $\begin{array}{l}56.7 \% \text { ( } 80 \text { of } 141 \\
\text { inmates on death } \\
\text { row) }\end{array}$ & 1.4 & \\
\hline
\end{tabular}

